\title{
Introduction to Part 5
}

The future, Marc Augé writes, "even when it concerns the individual, always has a social dimension: it depends on others" (Augé 2014: 2). ${ }^{1}$ The contributions grouped in this section get to the bottom of this statement. The authors show that the negotiation of futures is always about relationships sought, socially and individually, and about the political implications and normative configurations of these relationships.

In the first chapter, Adeline Masquelier questions the assumption that modern education entails a break with the past, particularly when school systems are dysfunctional and resource deficient, as in Niger. The globalized mobilization of 'girl power', she argues, is an alibi for the depoliticization of collective welfare and a step towards the privatization of responsibility and, ultimately, tyrannical futures.

George Paul Meiu enquires about queer practices of shaping the future in the second chapter. Based on the work of Kenyan artist Kawira Mwirichia, Meiu explores how such futures materialize amid and against a rising homophobic rhetoric. In the third chapter, Julia Pauli suggests that marriage in Namibia has changed into a (neoliberal) class-based, privileged institution. Unmarried Namibians, it is demonstrated, rely on kin networks rather than building their futures on heterosexual bonds.

The fourth contribution turns to the future of female genital mutilation. Tammary Esho analyses the growing demand for specialized medical services to replace traditional cutting, as well as a switch towards cosmetic genital surgery, suggesting that these changes threaten to slow down the progress achieved through decades-long campaigns to end these harmful practices.

In the fifth chapter, Akira Takada and Yuriko Sugiyama explore the rich ritualistic practices of two closely related San groups in Botswana, suggesting that the rituals are tools for conviviality and for the reconstruction of lifeworlds disturbed by state resettlement policies. The section concludes with a speculative short story by Martha Ndakalako. Drawing from black feminist futurity, her narrative envisions the connections and possible influences between women in Namibia and those in the diaspora.

1 Augé, M. 2014. The future. London: Verso. 


\title{
'Girling' the Future and 'Futuring' Girls in Niger
}

\author{
Adeline Masquelier
}

\section{Introduction}

"There are no rules against girls going to school, only the poverty of parents," three senior men from Zinder, Niger's second largest city, responded when I asked about the low school enrolment of girls in Niger. Echoing other Nigerien parents who described schools as "opening the mind" and "offering possibilities," they made clear that formal education figured prominently in the dreams they had for their children, including daughters. Yet, they also intimated that the path to social mobility was pitted with obstacles, frequently discouraging the best-intentioned parents from keeping daughters in school. For one thing, the quality of teaching had gone down in past decades. Moreover, schooling came at a cost. It exacted an especially heavy price from poor households dependent on the labour of girl children. In rural areas, where school is said to free youth from the "suffering of village life", parents noted philosophically that it was neither possible nor desirable for all children to complete their schooling. Their sobering comments are reflected in the numbers. While formal education in Niger is mandatory between the ages of seven and fifteen, school enrolment and attendance rates remain startlingly low, particularly for girls.

Girls' schooling, it is worth noting, was a cornerstone of the millennium and sustainable development goals, which rationalized the global turn to girls by yoking education to female empowerment. In recent years, national campaigns have heralded girls' education in Niger as a key strategy for enacting gendered social changes and confronting poverty. These campaigns in turn have inspired local sensitization projects that frame schooling as a catalyst for national development. In the 2015 issue of Echo des jeunes, a newsletter designed by a team of Dosso-based youths to inform, educate, and sensitize, ${ }^{2}$ a graphic vignette entitled 'Girls' education, the fight for development', encourages parents to grant their daughters bright futures by sending them to school. The vignette features a couple - rural dwellers judging from the farmer's hat the man is wearing - who finds out their young daughter Zara, who has been entrusted to a tutor in a nearby town so she can attend school there, is abused.

2 A Zarma-speaking town in southwest Niger, Dosso is a trading hub linking Niamey, the country's capital, to Benin and to eastern Niger.

(C) ADELINE MASQUELIER, 2022 | DOI:10.1163/9789004471641_026 
The couple just received a letter from Zara's teacher informing them that Zara is "treated like a slave" by her tutor. Zara's father, who sold two cows to pay for his daughter's room and board in town, is incensed. He sets off, determined to find another tutor for Zara, one who will properly look after her so she can do well in school. "Nothing has more impact on a nation than the education of girls," reads an accompanying statement. Parroting slogans coined by governmental organizations, charities, and NGO s to highlight the benefits of investing in girls, the statement casts female children as subjects imbued with unique potential, including the capacity to transform their country's fortunes. By framing the economic advancement of Niger as contingent on the education of its girl children, the vignette sends a clear message to readers: girls who go to school grow up to be resourceful, goal-oriented women who build businesses, empower their communities, and propel the country forward.

What the message leaves out is that the push to widen girls' access to education in Niger is part of a wide-scale effort to 'economize life' (Murphy 2017) in the Global South based on a neoliberal narrative of progress that correlates girls, education, fertility, and income. This narrative is built on the assumption that girls who complete their schooling (rather than marry early) postpone childbearing and enhance their wage-earning capacities. In the long run, they lower population growth while also improving their country's economic prospects. "Let's put her in a school uniform ... [and] she will do the rest," is the bold message of an award-winning video which the Nike corporation (not exactly a disinterested party as regards the financialization of self-empowerment narratives) put out to promote the Girl Effect, their philanthropic brand (The Girl Effect 2008). ${ }^{3}$

Launched in 2008 at the World Economic Forum in Davos, the Girl Effect campaign proposes a model of development in which the weight of the world's future rests on the frail shoulders of the female child - typically represented as a destitute girl from Africa. In this model, stubborn traditions (such as early marriage) are identified as the main challenge to girls' health, success, and empowerment. By attending school, girls escape the shackles of culture and become successful entrepreneurs. Schooling thus emerges as the most effective tool for unlocking girls' potentialities and, down the line, putting an end to chronic poverty. The notion that girls are entrepreneurial "subjects in waiting" (Koffman and Gill 2013: 105) who, if only given a chance, overcome marginalization and empower communities has led to a flourishing of initiatives aimed

3 In 2015, the Girl Effect split from the Nike Foundation to become an independent NGO. 
at enhancing girls' and young women's educational and economic opportunities in the Global South.

According to the Girl Effect telos, the future follows a predictable trajectory determined by global capital: a corporate donor's financial investment in a girl's formal education triggers a cascade of events that ultimately produce a better world (Thakor 2011). In the 2008 Girl Effect video, a cow purchased with a loan by the educated girl becomes a herd, the herd turns the girl into a businesswoman who brings clean water to her village; her success prompts men to invite her to the village council, and so on.

In this chapter, I interrogate the conceptualization of futurity that philanthrocapitalism peddles through a reliance on "anticipatory ... calculations of value" (Murphy 2017: 115) that cast poor girls as lucrative investments. Focusing on spiritual attacks taking place in secondary schools in Niger, I discuss how the possession of schoolgirls by vengeful spirits obsessed with the past troubles the teleology of neoliberal narratives of female empowerment that frame schooling as a critical step along an upward trajectory. I suggest that the mobilization of 'girl power' - an alibi for the systematic depoliticization of collective welfare and the privatization of responsibility - ultimately produces tyrannical futures that, by requiring significant sacrifices, may well make the present uninhabitable.

\section{Making Futures}

More than any other institution, modern education conjures possibility, promise, and futurity (Agnagnost 2008; Stambach 2017). It frames dreams and desires based on the promissory nature of human capital. Put simply, school is where one invests in the future. In the Global South, schools are said to nurture aspirations by breaking with traditions (Stambach and Hall 2017). The overly optimistic modernization models guiding development policies portray education as a catalyst of social change, harnessing the potentialities of youth for the benefit of the nation (Stambach 2000). Rather than building on a shared past, schools serve as incubators of a common, and importantly, preordained future.

In Niger, where schools are routinely described as engines of progress, girls' education is now the unprecedented focus of humanitarian and developmental attention. Adopting a "school-to-the-rescue" (Stambach 2000) model of development that casts girls' education as the pathway to self-empowerment, gender rights activists and development workers unveil initiatives, including scholarships, conditional cash transfers, and basic school facilities like clean 
drinking water and toilets. During campaign visits, workshops, and public broadcasts, they flaunt girls' schooling as the solution to a number of societal issues, including 'child' marriage, uncontrolled fertility, poverty, underdevelopment, and gender inequality. Schoolchildren are taught mantras such as "when a girl attends school, the whole nation matures." Parents are urged by community leaders to take girls' education seriously. Girls are featured on billboards advertising loans to parents needing cash to purchase school supplies, while posters show responsible fathers dropping off their daughters to school and encouraging others to do the same. Meanwhile, through a creative blend of feminist and financial calculations of value, big players like the World Bank imbue Nigerien girls with the capacity to unleash financial growth, empower communities, and lift entire countries out of poverty. In the words of World Bank president Jim Yong Kim, "if girls are equipped with the education and human capital they need, they have the potential to secure the future of their countries" (World Bank 2018).

In Niger, the least educated country on the planet, not all children attend school. Significantly, those who will never see the inside of a classroom are more likely to be girls. Despite the government's commitment to gender equity and the array of legal instruments, strategies, and policies initiated by multilateral donors, sizeable gender disparities remain with regards to educational opportunities and outcomes. While female primary school participation rests at just over 50 per cent, the literacy rate for women between the ages of 15 and 25 is less than 25 per cent. Predictably, the poorest girls are least likely to complete primary school. The promotional campaigns and development projects targeting girls and funded by the US Department of State, the United Nations, and transnational NGO s as well as corporate responsibility projects, such as the Girl Effect, are part of a global effort to combat social inequality and narrow the gender gap. With an eye to curbing Niger's birth rate, they have attempted to shape compulsory school attendance policies (on the assumption that girls attending school postpone marriage and childbearing). These efforts have been challenged, highlighting how boko (Western education) has become a lightning rod for Muslim activists' discontent with foreign intervention: in 2012 the Nigerien government, pressured by a group of Islamic associations, abandoned a bill aimed at protecting the right of girls to attend school until 18. It later issued a decree preventing the marriage of girls for as long as they attended school.

Projects aimed at curbing population growth by keeping girls in school function within "gendered fields of justification for intervention" (Scully 2011: 27) saturated by the neoliberal rhetoric of female empowerment. The implementation of structural adjustment programmes in Niger resulted in market deregulations, shrunk public services, and flexible employment structures. 
People were expected to rely less on government and more on themselves. Under this new social contract, education was touted as the path forward in an increasingly competitive labour market. The catch-all term 'girls' education' here refers to a tangle of issues centred on the empowerment of girls and women. It encompasses gender equality and access to education as well as broader problems, such as poverty alleviation. Ironically, what the language of female empowerment obfuscates is that these interventions are less about education (that is, preparing for the future) and more about schooling as a project that, by engaging girls in age-appropriate activities, delays marriage and motherhood. Put differently, schooling is ultimately about presenting girls, so they don't grow up too fast.

Like other pamphlets, posters, and sensitization messages I came across over the years, the vignette about Zara's struggles puts the accent on the investment parents should make to ensure girls thrive in school. By presenting the case of an ordinary farmer who believes his daughter "must succeed just like every other girl in the country", the vignette encourages other parents to commit to their daughters' education, regardless of what obstacles surface. It makes clear that it is not only Zara's future but also the future of the country that is at stake.

Many girls seem to have absorbed the notion that they are agents of change. "School helps us pull our parents out of poverty" is a common refrain I heard, that hints at the responsibilization that education entails. Girls speak of attending school so they can make the world a better place. "Once I become a judge, I will send my parents to Mecca and help my village," a schoolgirl said. In the neoliberal vision of development, the investable girl - described as both the poorest and "the most powerful person in the world" (Murphy 2013) - is implicitly propped up against the threat posed by rebellious youth - adolescent boys whose lack of compliance (or idleness) imperils the planet's biopolitically engineered futures. In sum, the girl is not only a repository of future capital, she is also a national security solution. ${ }^{4}$

\section{$3 \quad$ Cruel Promises}

The girl-centred model of education is based on the assumption that hard work is key to individual success. Accordingly, students who make school their

4 Yoking economic calculus and feminist notions of empowerment with tired clichés, journalist Nicholas Kristof (2015) writes about the demographic and other benefits of educating girls in war-torn countries: "Education is also a bargain. For the cost of deploying a single American soldier abroad for a year, we can start more than 20 schools." He concludes that "sometimes a girl with a book is more powerful than a drone in the sky." 
priority are a step closer to achieving their dreams. Yet, the myth of meritocracy obscures social inequalities as well as other challenges students, especially girls, face. It takes more than determination to succeed in school, as Niger's education statistics reveal. Take retention rates, for instance. While more Nigerien children than ever are currently enrolled in primary school, 30 per cent of these children will drop out before reaching middle school. And more will leave before they reach high school. The problem is particularly acute for girls. Only one out of ten girls ends up in high school. Even there, educational trajectories can easily be derailed.

Recall that the primary aim of Girl Effect and other projects is to keep adolescent girls in school so they postpone marriage. Niger, which leads the world when it comes to the practice of mariage précoce (early marriage), has been the focus of numerous interventions designed to rescue girls from prejudice and patriarchy. Education is a human right, girls' rights activists and other liberal actors argue as they frame local 'custom' as an impediment to progress and gender justice. The moral arguments deployed by human rights activists to eradicate mariage précoce have earned limited traction in Niger, especially in rural areas, where they often compete for legitimacy with an Islamic model that defends early marriage as morally suitable for girls and their families (Masquelier 2020a). Adolescent girls face enormous pressure to conform to pious norms of Muslim femininity and domesticity; many leave school to marry and start families (roughly 50 per cent of Nigerien girls are married by the age of 15). In households that rely on their labour, the girls' academic requirements compete with domestic duties or income earning occupations (as the case of Zara demonstrates, girls are easily exploited, and the gift of a scholarship only partly alleviates the problem). In some cases, the sexual harassment and other forms of sexual violence girls confront in school constitute significant obstacles to the completion of their studies. ${ }^{5}$ They undermine the Girl Effect depiction of schools as safe places offering protection from pregnancy, STD s, prostitution and other threats.

What does it mean to invest in girls as 'human capital' when school systems are dysfunctional and resource deficient? Girls may well dream of becoming teachers, lawyers or doctors, but in contexts where the quality of education has worsened and inequalities have deepened, such dreams often remain out of reach. Liberal feminist discourses that bind narratives of girl power, individualism, and 'just do it' subjectivity with the language of revolution - "Girls are

5 A 2004 study of sexual violence against girls in secondary schools and higher education reported that more than $5^{\circ}$ per cent of secondary girls have been victims of sexual harassment or rape (UNICEF 2004). 
the most powerful force for change on the planet" the Nike Foundation asserts on its webpage - paper over the structural features of neoliberal capitalism that generate the very global inequalities the Girl Effect professes to address (Koffman and Gill 2013). In impoverished countries like Niger, the promise of education dangled by politicians, corporate elites, development workers, and rights activists often turns out to be 'cruelly optimistic' (Berlant 2011).

There is another sign that in its current state education may not be the panacea envisioned by the Girl Effect. Secondary schools throughout the country are experiencing outbreaks of spirit possession. Adolescent schoolgirls are targeted by violent, vindictive spirits seeking justice for wrongs suffered in the past. Possession is often contagious. Minutes after a girl shows signs of being overtaken by an invisible force, several others in her vicinity will exhibit similar symptoms. The incidents have raised concerns about school safety, prompting debates about the place of girls in school and the role of secular education in Niger, ${ }^{6}$ a Muslim-majority country where Islam has assumed an increasingly visible role (Masquelier 2009). Besides wreaking havoc in schools and forcing establishments to close momentarily, possession often brings great disarray in the victims' lives (Masquelier 2020c). Some girls recover but others must abandon school.

Through the voice of the possessed, spirits reveal how they lost their homes when the trees they inhabited were felled to make room for schools. By reappearing years later to broadcast grievances, they force people to confront a past that never ends. At another level, these tales of eviction point to a broader history of iconoclasm aimed at purifying Islam from unwarranted innovations. In the last century, Niger witnessed waves of religious fervour that resulted in the erasure of spirit-centred practices in some regions. In Arewa, the Hausaspeaking region where I have conducted research since the late 1980s, spirit possession, once a central dimension of health-seeking practices, became progressively vilified as a source of immorality and an index of backwardness (Masquelier 2001).

In schools where spiritual attacks took place, the presence of spirits is generally understood through the lens of the past - a past that puts constraints on the present. School administrators and government officials occasionally finance purification rituals to rid the establishment of spirits. Though these procedures are said to be effective, one can never be sure that the spirits have left for good. A school director I knew turned on recordings of Koran recitations at night in some classrooms to keep the spirits at bay. Many people told

6 Spirits have been known to haunt faith-based schools (école franco-arabes). Nevertheless, most possession incidents I have heard of occurred in secular schools. 
me the schools were haunted. Some teachers warned students not to wander in parts of the school suspected of being 'infested' with spirits. Here the past is apprehended as a looming menace, an unwanted burden threatening to overtake the present. Spirit attacks are perceived as the inevitable offshoots - the never-ending ripples - of a violent, iconoclastic past (Masquelier 2020b). Since one does not know when and where the spirits will strike next, there is a great deal of uncertainty. Yet life must go on, children must attend school. In such contexts, time is experienced "in the tension between the visible and the invisible, presence and absence, voice and silence" (Lambek 2002: 29). The present people inhabit is fissured. The uncanny infiltrates ordinary life through the fissures, constraining agency and reshaping trajectories.

Once, in July I visited a middle school in Dogondoutchi, a town in Arewa I have come to know well. The place stood silent and empty, devoid of the laughter, babble and animation that typically filled the air during the school year. I cautiously avoided the beans stalks planted at regular intervals across the entire schoolyard (during the rainy season people grow food wherever they can). My guide, the head of the school's parent association, was more worried about inadvertently disturbing a spirit. He proceeded guardedly, warning me to follow him and not to go near the latrines (which can be dangerous since spirits are known to congregate in 'dirty' places). I felt at times as if I were walking in a minefield. At last we stopped by the water pump where, a year or so before, a girl had been attacked by a spirit, setting off wild pandemonium among students (some of whom became possessed) and forcing the authorities to cancel classes momentarily. As we were leaving, the man pointed to the wall surrounding the school and, from a distance, I noticed that part of it had collapsed. He blamed today's brash, undisciplined male youths for the damage: "They have no respect, these delinquents. They jump over the walls and they shit in the schoolyard. I attended this school as a child. Back then it was a nice place; kids were well-behaved. Now this place is going to the dogs."

To do justice to the stories of nostalgia and haunting, hope and failure, trance and iconoclasm that bind together schools, spirits, and adolescent girls in Niger, one must let go of the notion that time unfolds in a sequential, unidirectional, and predictable fashion. A number of social theorists have recently come to reject the conceptual primacy of 'the future' (Berlant 2011; Goldstone and Obarrio 2017) while others have disrupted our models of linear time and progressive history (Chakrabarty 2000; Derrida 1994). Drawing on 
their insights, I have argued that insofar as schools in Niger encode potentialities, these potentialities do not necessarily spawn foreseeable trajectories. It is not simply that these schools typify the inadequacy of the Girl Effect and its cohort of assumptions (and speculations) about girlhood, agency, capital, and futurity. They are also instantiations of temporal entanglements. The "time of entanglements", Achille Mbembe (2001) notes, is not a linear series of events in which each moment annuls and replaces the moments that preceded it. It is instead an "interlocking of presents, pasts, and futures that retain their depths of other presents, pasts, and futures, each age bearing, altering, and maintaining the previous ones" (Mbembe 2001: 16). This time is made up of disturbances, "bundles of unforeseen events" (Mbembe 2001: 16), that unsettle the modernist perception that history proceeds in a straight, segmented line a sequence of events and their aftermaths (Hunt 2016).

By troubling the assumption that modern education entails a break with the past, the possession of Nigerien schoolgirls offers a demonstration of what Mbembe's temporal disturbances entail. It points to the limitations of models of development based on irreversible, future-oriented temporalities for capturing how people inhabit time. When raging spirits irrupt in classrooms to demand redress for past injuries, a troubled past is uncovered that stubbornly refuses to go away. This past is 'imperfect' (Lambek 2002: 12) in the sense that it is incomplete and unruly. In her work on imperial formations, Ann Stoler (2008: 196) invokes the concept of ruination to register the 'protracted quality' of damages to bodies, landscapes, and relationships. From this perspective, the spirits' expulsion from their homes may be described as a single event, but it is more accurately captured through its multiple, diffuse, enduring effects. After Mina, a 17-year-old girl, became possessed by a spirit at school, she was never the same. Hoping for a cure, her mother took her to a number of healers. Mina kept having terrifying visions. She slept poorly and did not eat much. She was afraid to leave the house. She never stepped foot in school again.

By interrupting school life and wreaking educational trajectories, spiritual attacks uncover the imperfectness of the past while putting the accent on the tyranny of futurity - the kind of ideology of progress that is at work in Zara's story. Built around the premise that schools are engines of development, the story hints at the ways the future is girled and girls are futured in Niger. Schoolgirls themselves routinely imagine and plan for the futures that education, in theory at least, opens up for them. For some of them, however, the aspirations that unfold against a teleological horizon of progress are too burdensome. They require a faith in 'girl power' that social realities, including the widespread recognition that a woman's worth depends on her fertility, frequently undermine. 
The oppressive logic governing the promise of a better tomorrow, that is, the perception that events are the realization of a predetermined telos, is what Elizabeth Povinelli (2011) calls the 'future perfect'. As an aspirational mode that frames current hardship as the necessary precursor to futurity, the future perfect demands sacrifice, such as the investment poor Nigerien parents make in their daughters' education to secure a redeeming future. Recall the two cows that Zara's father sold so that she could go to school. In a very real sense, some Nigerien schools are haunted by the violence of the past as much as by the promises of the future.

\section{Acknowledgements}

I am indebted to all the Nigeriens who discussed their views of education and their experiences of spirits, haunting, and possession with me. My research in Niger was supported by Tulane University as well as the National Geographic Society. I thank the editors and the anonymous reviewers for their helpful comments and suggestions.

\section{References}

Agnagnost, A. 2008. "Imagining global futures in China: The child as a sign of value." In Figuring the future: Globalization and the temporalities of children and youth, edited by J. Cole and D. Durham, 49-72. Santa Fe: School for Advanced Research Press.

Berlant, L. 2011. Cruel optimism. Durham, NC: Duke University Press.

Chakrabarty, D. 20oo. Provincializing Europe: Postcolonial thought and historical difference. Princeton: Princeton University Press.

Derrida, J. 1994. Specters of Marx: The state of the debt, the work of mourning, and the new international. New York: Routledge.

Goldstone, B. and J. Obarrio (Eds). 2017. African futures: Essays on crisis, emergence, and possibility. Chicago: University of Chicago Press.

Hunt, N. R. 2016. A nervous state: Violence, remedies and reverie in colonial Congo. Durham, NC: Duke University Press.

Koffman, O. and R. Gill. 2013. "The revolution will be led by a 12-year-old-girl": Girl power and global biopolitics. Feminist Review, 105: 83-102.

Kristof, N. 2015. "Smart girls vs. bombs." New York Times, 11 April. https://www.nytimes. com/2015/04/ 12/opinion/sunday/nicholas-kristof-smart-girls-vs-bombs.html $[15$ February 2020].

Lambek, M. 2002. The weight of the past: Living with history in Mahajanga, Madagascar. New York: Palgrave Macmillan. 
Masquelier, A. 2001. Prayer has spoiled everything: Possession, power, and identity in an Islamic town of Niger. Durham, NC: Duke University Press.

Masquelier, A. 2009. Women and Islamic revival in a West African town. Bloomington: Indiana University Press.

Masquelier, A. 2020a. "Early marriage and the debates over gender-based rights in Niger." In Legislating gender and sexuality in Africa: Human rights, society, and the state, edited by E. Burrill and L. Boyd, 42-64. Madison: Wisconsin University Press.

Masquelier, A. 2020b. "A matter of time: Spirit possession and the temporalities of school in Niger." Journal of Africana Religions, 7, 1: 122-145.

Masquelier, A. 2020c. "A disenchanted landscape? Jinn, schoolgirls, and the demonization of the past in Niger." Preternature, 9, 2: 243-266.

Mbembe, A. 2001. On the postcolony. Berkeley: University of California Press.

Murphy, M. 2013. "The girl: Mergers of feminism and finance in neoliberal times." The Scholar and Feminist Online, 11.1-11.2. http://sfonline.barnard.edu/gender-justiceand-neoliberal-transformations/the-girl-mergers-of-feminism-and-finance-inneoliberal-times/ [22 February 2020].

Murphy, M. 2017. The economization of life. Durham, NC: Duke University Press.

Povinelli, E. A. 2011. Economies of abandonment: Social belonging and endurance in late liberalism. Durham, NC: Duke University Press.

Scully, P. 2011. "Gender, history, and human rights." In Gender and culture at the limit of rights, edited by D. L. Hodgson, 17-31. Philadelphia: University of Pennsylvania Press.

Stambach, A. 2000. Lessons from Mount Kilimanjaro: Schooling, community, and gender in East Africa. New York: Routledge.

Stambach, A. 2017. "Student futures and the politics of possibility: An introduction." In Anthropological perspectives on student futures: Youth and the politics of possibility, edited by A. Stambach and K. D. Hall, 1-16. New York: Palgrave Macmillan.

Stambach, A, and K. D. Hall. 2017. Anthropological perspectives on student futures: Youth and the politics of possibility. New York: Palgrave Macmillan.

Stoler, A. L. 2008. "Imperial debris: From ruins to ruination." Cultural Anthropology, 23, 2: 191-219.

Thakor, M. 2011. "The Girl Effect: A whole new way to invest." Forbes, 4 October. https:// www.forbes.com/sites/manishathakor/2011/10/04/the-girl-effect-a-whole-newway-to-invest/\#3282feoa1177 [25 February 2020].

The Girl Effect. 2008. "The girl effect." https://www.youtube.com/watch?v=WIvmE4_ $\mathrm{KMNw}$ [25 February 2020].

UNICE F. 2004. Annual report. https://www.unicef.org/publications/index_27262.html. World Bank. 2018. World Bank invests US \$3.2 billion in adolescent girls' education in 2 years. https://www.worldbank.org/en/news/press-release/2018/o3/o7/world-bankinvests-us32-billion-in-adolescent-girls-education-in-2-years [10 February 2020]. 